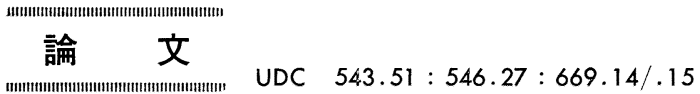

\title{
IMMA による鋼中ボロン分析
}

\author{
白岩 俊男* ·藤野 允克* ·村山順一郎 ${ }^{* 2}$ \\ Ion Microprobe Mass Analysis of Boron in Steel
}

Toshio Shirajwa, Nobukatsu Fujino, and Jun'ichiro Murayama

\begin{abstract}
Synopsis :
Ion microprobe mass analyzer has been applied to analysis of boron in high strength steels. It is proved that the analytical technique has sufficient sensitivity and resolution to determine the distribution of boron in precise correspondence with metallogrophic microstructure. It is also shown that quantitative analysis of bolon in solid solution is possible, and that the effect of nitrogen on the amount of solute boron can be detected.
\end{abstract}

\section{1. 緒言}

鋼中に微量のBを添加することにより焼入性が问上す ることを利用した高張力鋼が最近開発されている．鋼中 でのB添加に詨する効果の調查は，従来主として金相学 的な研究すなわち金相組織との対応で析出抢よび固溶早 と，熱処理との関係を電子顕微鏡，化学分析あるいは扎 出物のX線回折による調查から挙動がほぼ明らかにされ ている. B 添加の効果を簡単にいうと焼入時にオーステ ナイト粒界に偏析しているBによつて粒界でのフェライ ト生成を抑制することであり，粒界でのBの偏析および 固溶Bの直接分析の手段としては，EPMA では感度が 低くオージェ電子分光による粒界分析でもほとんど成功 した例はない。この面から IMMA は局所分析であるこ と，Bに対して極めて高感度であることから有力な手段

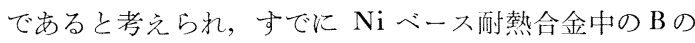
析出に関して $\mathrm{WALSH}^{2)}$ が，また $50 \mathrm{ppm}$ 添加低合金鋼 について MAITREPIERRE3)45) らが IMMA による析出 物と光学顕微鏡組織㸩よびアルファログラフィとの対応 を調查している。本報では ARL 製の IMMA を用い
て重星含有率 $85 \mathrm{ppm}$ 扰よび $15 \mathrm{ppm}$ のB添加鋼を対

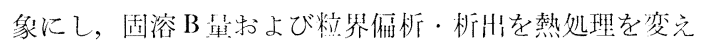

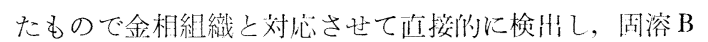
については蓬早的な测定が得られたので郝告する。

\section{IMMA の B に対する検出感度}

IMMA による鉄鋼中の微古元䒺に対する检州感度を 知るために, $1250^{\circ} \mathrm{C} \times 1 \mathrm{~h} \mathrm{inAr} \rightarrow W . Q . の$ 溶体化熱処理 を行つた NBS 1167 および 1168 小の元素の検出感度 を求めた。测定は佂料調整時の表而活染雇（通常の表面 污染層の厚さは約 $200 \AA$ ) を除去与るため $\mathrm{O}_{2}^{+} 1$ 次イオ ン， $10 \mathrm{kV}, 200 \mathrm{nA} て ゙ 400 \mu \times 320 \mu$ 而䅡を 500 秒問連 続してスパッター（このスパッター条作では衣而より約 $400 \AA$ が除去される。) し海沵西を得たあと行つた。測定 条件は 1 次イオンビームを $2 \mu \phi$ と呅小に絞つた場合の 検出感度を求めるため, 2 次イオン収早が闪くな $\mathrm{O}_{2}^{+}$ 1 次イオンビームを $10 \mathrm{kV}$ で加速し, 1 次イオン電流は 2 次イオン強度とビーム徍との兼合いより $1.5 n A$ と設 定した。そして計数時間 $10 \mathrm{~s}$ に打ける检出限貥を算出 し，EPMA のそれと比較した。検出限界は傍晃レベル

昭和 50 年 10 月本会講演大会にて発表 昭和 54 作 5 月 2 日受付 (Received May 2, 1979)

* 住友金属工菜(株) 中央技術研究所 理博 (Central Research Laboratories, Sumitomo Metal Industries, Ltd.)

*2 住友金属工業(株) 中央技術研究所 (Central Research Laboratories, Sumitomo Metal Industries, Ltd., 1-3 Nishinagasuhondori Amagasaki 660) 


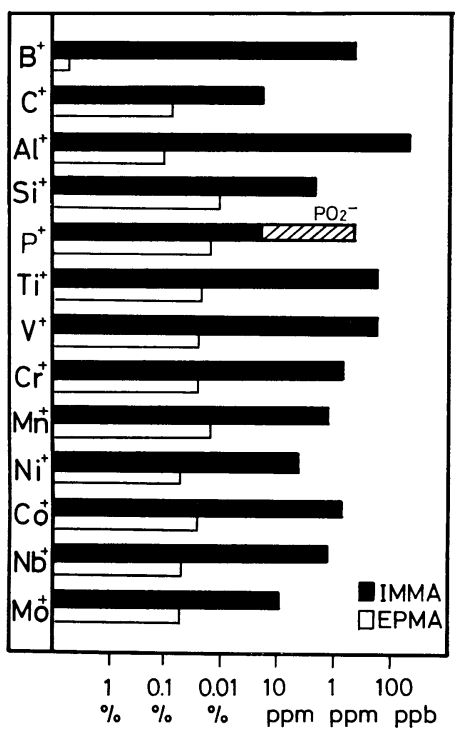

Fig. 1. Detection limits of IMMA and EPMA for trace element in low alloyed steel.

とバックグラウンドレベルをほぼ 100\% 分離させるため に3。をとる次式にて与えた ${ }^{6)}$.

$$
\mathrm{C}=\frac{3 V 2 \cdot V I_{\mathrm{R}}}{I} \cdot W
$$

ここで $C ;$ 検出限界重量パーセント

$$
I \text {; 測定カウント数 }
$$$$
I_{\mathrm{B}} ; \text { バックグラウンドカウント数 }
$$$$
W \text {; 試料中の成分含有重量パーセント }
$$

これによつて求めた結果を Fig. 1 に示す.この結果か らも明らかなよらにBに対しては EPMAでは感度が低 く数パーセント以トでないと検出できないが，IMMA では ppm オーダまで十分に検出できるので, 鋼中に微 量添加されるBの固溶 $\mathrm{B}$ まで分析でき得ると考えられ， また局所分析であることから粒界の偏析がたと極めて 薄い層であつてもビーム径内での感度としては十分に検 出可能と考えられる.

\section{3. 供試料と熱処理}

本調査に用いた供試料は Total $\mathrm{B}=85 \mathrm{ppm}$ と B 含有
量の多いものと, Total $\mathrm{B}=15 \mathrm{ppm}$ と少ないものの 2 種類の試料についてである. これらの化学分析值を Table 1 に示す. Total $\mathrm{B}=85 \mathrm{ppm}$ に次の 3 種の熱処 理を行つた。

(1) $1250^{\circ} \mathrm{C} \times 30 \mathrm{~min} \rightarrow \mathrm{W} . \mathrm{Q}$.

(添加 Bを十分に固溶させる熱処理)

(2) $1250^{\circ} \mathrm{C} \times 30 \mathrm{~min} \rightarrow \mathrm{W} . \mathrm{Q} .+650^{\circ} \mathrm{C} \times 1 \mathrm{~h} \rightarrow \mathrm{A} . \mathrm{C}$ (オーステナイト粒界に $\mathrm{Fe}_{3}(\mathrm{C}, \mathrm{B})$ として析出さ る熱処理)

(3) $1250^{\circ} \mathrm{C} \times 30 \mathrm{~min}+900^{\circ} \mathrm{C} \times 1 \mathrm{~h} \rightarrow \mathrm{W}$. Q.

(添加 Bを完全析出させる熱処理)

な括これら熱処理を施した試料については電子顕微鏡で の薄膜観察により調査されて执り1)，Bの存在がおの括 のオーステナイト粒界への偏析, $\mathrm{Fe}_{3}(\mathrm{C}, \mathrm{B})$ としての微 細析出, $\mathrm{M}_{23}(\mathrm{C}, \mathrm{B})_{6}$ として析出していることが調査確認 されている. Toal B=15 ppm 試料 (Sample A) につ いても同様の目的で次の 3 種の熱処理を施した.

(1) $1250^{\circ} \mathrm{C} \times 60 \mathrm{~min} \rightarrow \mathrm{W} . \mathrm{Q}$.

(オーステナイト域での溶体化熱処理)

(2) $1250^{\circ} \mathrm{C} \times 60 \mathrm{~min} \rightarrow \mathrm{W}$. Q. $+1000^{\circ} \mathrm{C} \times 60 \mathrm{~min} \rightarrow$

W. Q. $+930^{\circ} \mathrm{C} \times 90 \mathrm{~min} \rightarrow$ W. Q.

(オーステナイト粒界一偏析させる熱処理)

(3) $1250^{\circ} \mathrm{C} \times 60 \mathrm{~min} \rightarrow \mathrm{W}$. Q. $+630^{\circ} \mathrm{C} \times 90 \mathrm{~min} \rightarrow$

W. Q.

(添加 Bを完全析出させる熱処理)

なお以上の熱処理はいずれもAr雲囲気で行つた。

\section{IMMA 測定条件}

本調査に用いた装置は ARL 製 IMMA であり測定 条件は次のと打りである.

\section{1 次イオン種; $\mathrm{O}_{2}^{+}$イオン}

加速電压 $;+20 \mathrm{kV}$

$$
\text { ビーム径; } 2 \mu \phi \text { (Point or Raster) }
$$

検出 2 次イオン; ${ }^{11} \mathrm{~B}+$ イン (ただし CARISMA 計算を行う場合には ${ }^{16} \mathrm{O}^{+},{ }^{32} \mathrm{O}_{2}^{+},{ }^{44} \mathrm{Fe}^{+},{ }^{60} \mathrm{Ni}^{+}$ も検出した.)

なおこれらの測定条件設定の理由は 2 次イオン収量を高

\begin{tabular}{|c|c|c|c|c|c|c|c|c|c|c|c|c|c|}
\hline Sample & & $\mathrm{C}$ & $\mathrm{Si}$ & $\mathrm{Mn}$ & $\mathrm{P}$ & $\mathrm{S}$ & $\mathrm{Cu}$ & $\mathrm{Ni}$ & $\mathrm{Cr}$ & Mo & $\mid$ Sol Al & $1 \mid \begin{array}{c}\text { Total } \\
\mathrm{B}\end{array}$ & $\begin{array}{c}\text { Total } \\
\mathrm{N}\end{array}$ \\
\hline High boron steel & & 0.19 & $<0.01$ & $<0.01$ & 0.002 & 0.005 & $<0.01$ & $<0.01$ & $<0.01$ & - & $0.034 \mid \mathrm{C}$ & 0.0085 & 0.007 \\
\hline \multirow{2}{*}{ Low boron steel } & $\mathrm{A}$ & 0.09 & 0.31 & 0.90 & 0.005 & 0.008 & 0.24 & 1.00 & 0.47 & 0.46 & 0.066 & 0.0015 & 0.002 \\
\hline & $\mathrm{B}$ & 0.11 & 0.29 & 0.89 & 0.008 & 0.010 & 0.24 & 1.00 & 0.46 & 0.45 & 0.068 & 0.0015 & 0.006 \\
\hline
\end{tabular}
くするために $\mathrm{O}_{2}^{+}$イオンを用い，オーステナイト粒界

Table 1. Composition of boron bearing steel. 


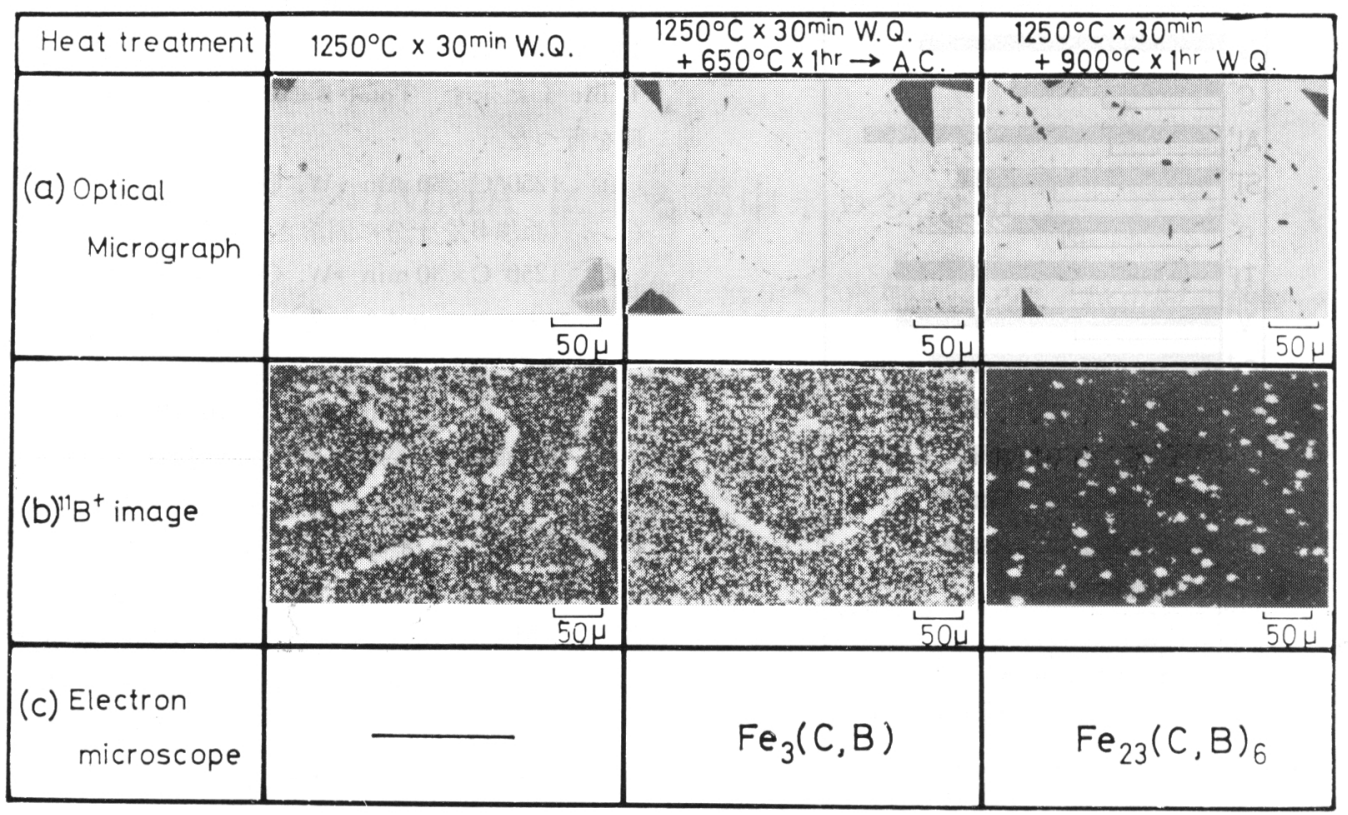

Photo. 1. Microanalysis of boron bearing steel $(B=85 \mathrm{ppm})$.

偏析のよらな極めて狭い領域を分析するために 1 次イオ ン加速電圧を $+20 \mathrm{kV}$, ビーム径を $2 \mu \phi$ と乙, 粒界や 粒内での 2 次イオン強度を連続して測定する場合には線 分析法すなわち 1 次イオンをPoint 静止させ試料を直 線駆動させる方法を, また 2 次イオンの二次元的分布強 度の像を得る場合には 1 次イオンをRaster する面分析 法により行つた。束た用いた ARL 製 IMMA では 1 次イオンビームを $2 \mu \phi$ と細束するためには $2 \times 10^{-9} \mathrm{~A}$ (in Faraday Cup) 以下のイオン電流と制限された。 し たがつてここでは 1 次イオン電流を $2 \times 10^{-9} \mathrm{~A}$ と選定し た.

\section{IMMA 分析}

IMMA による調査は光学顕微鏡で観察した組織と対 応させた状態で分析するため，上記熱処理試料をピクラ ールでエッチングを行いオーステナイト粒界を出現させ た. IMMA 分析では比較的試料表面からの情報が得ら れるため分析表面はェッチ組織でない方が望ましい。こ のためミクロビッカースにより目的場所を定めたあと研 磨を行つた。 以下 IMMA 分析はこれらの場所で表面污 染層を完全に除去するため約 $1000 \AA$ Sputter-off する Pre-Sputtering を行つたあと実施した。

(A) Total $\mathrm{B}=85 \mathrm{ppm}$ 材の IMMA 分析

上記 3 種の熱処理を行つた試料のオーステナイト粒界 エッチング組織写真および同一場所の IMMA による
${ }^{11} \mathrm{~B}^{+}$イオン像，それに電子顕微鏡薄膜観察結果を Photo. 1 に示寸が, 熱処理(1)での $\mathrm{IMMA}^{11} \mathrm{~B}^{+}$イオン 像は組織写真でのオーステナイト粒界と完全に一致した 所で明瞭な B 濃縮が検出された。電子顕微鏡調查結果か らはBの析出物が何ら認められないと報告されているこ とから, オーステナイト粒界に偏析したBが検出されて いると考光られる。(な沶IMMAによる ${ }^{11} \mathrm{~B}^{+}$イオン像 が粒界で点列状に見えるが，エッチングの影響によるも のであつて析出物が存在するためではない)熱処理(2)の 試料について同様に調査した結果, ${ }^{11} \mathrm{~B}^{+}$イオン像は組織 写真のオーステナイト粒界と一致した所と一部粒内に析 出したものが観察された. IMMA での 2 次イオン検出 では一般に原子濃度が同じでも酸化物や炭・窒化物とし て存在する場合に 2 次イオン強度は明瞭に高くなり ${ }^{8)}$, 電子顕微鏡調査からこれらの析出物が $\mathrm{M}_{3}(\mathrm{C}, \mathrm{B})$ 型で あると報告されて打り ${ }^{1)}$ ，IMMA で検出される析出物 も同じ存在形態を呈するものと判断された. 熱処理(3) の試料について調查した結果, IMMA の ${ }^{11} \mathrm{~B}^{+}$イオン 像からは他の結果とは異なり金相組織とは無関係に多数 の小さな粒状の析出物が観察された。これについては電 子顕微鏡調査で $\mathrm{M}_{23}(\mathrm{C}, \mathrm{B})_{6}$ であることが同定されてい る1).

以上のように IMMA では従来からの知見 ${ }^{1)}$ に一致し た B 分析が直接的に高感度分析可能なことが実験的に確 認された。このことからこれら熱処理の異なる試料での 


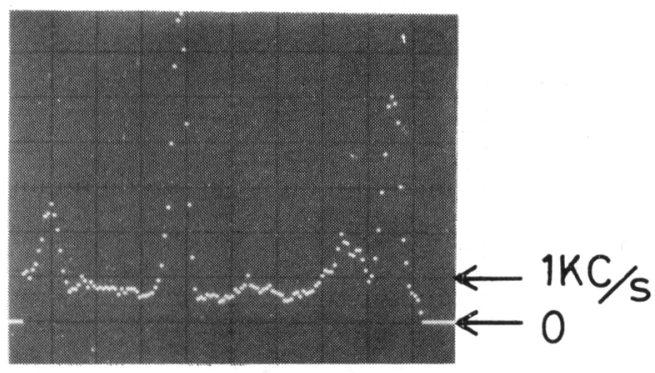

$1250^{\circ} \mathrm{C} \times 30 \mathrm{~min}$. W.Q.

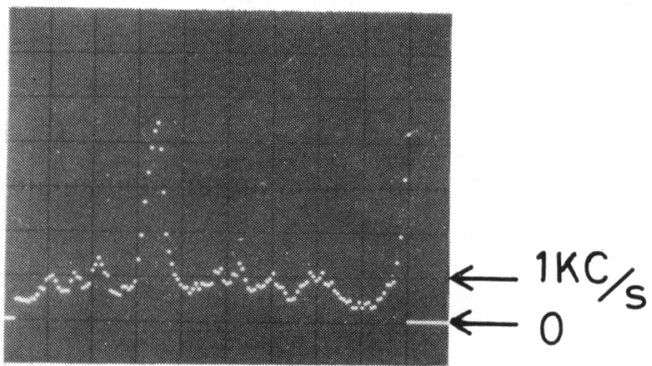

$1250^{\circ} \mathrm{C} \times 30 \mathrm{~min} . \mathrm{W} . \mathrm{Q}$.

$+650^{\circ} \mathrm{C} \times 1 \mathrm{hr}$. A.C.

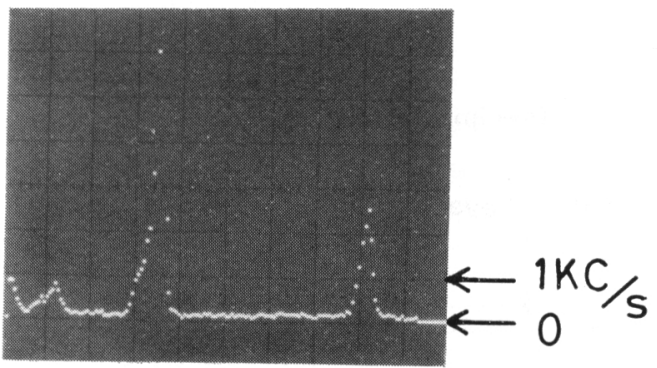

$1250^{\circ} \mathrm{C} \times 30 \mathrm{~min}$. W.Q.

$+900^{\circ} \mathrm{C} \times 1 \mathrm{hr} . \mathrm{W} . \mathrm{Q}$.

Photo. 2. Step scan analysis of $B(B=85 \mathrm{ppm})$.

析出物あるいは偏析部以外の固溶 B 量を IMMA の測定 感度をさらにあげて調査した。調査は 1 次イオンビーム 径䘮 $2 \mu \phi$ に絞り静止さ也, 試料を $1 \mu / \mathrm{s}$ の速度で直 線駆動させる線分析で 3 試料とも同一測定感度に沶いて 行つた. 調查結果を Photo. 2 に示す. 熱処理 (1) と (2) の試料でのマトリックス ${ }^{11} \mathrm{~B}^{+}$イオン強度はいずれも約 $0.8 \mathrm{kc} / \mathrm{s}$ と十分検出されているが，熱処理(3)の試料では マトリックス ${ }^{11} \mathrm{~B}+$ イオン強度は約 $0.1 \mathrm{kc} / \mathrm{s}$. と明らか に少なく，このことから熱処理(3)では鋼中に添加された $\mathrm{B}$ は汪とんどすべて $\mathrm{M}_{23}(\mathrm{C}, \mathrm{B})_{6}$ として析出してしま つていることが確認された，(ここで用いた $\mathrm{kc} / \mathrm{s}$. は $\times 10^{3} \mathrm{cps} / \mathrm{s}$. を意味する.) 以上 Total $\mathrm{B}=85 \mathrm{ppm}$ と $\mathrm{B}$ 量の多い材料での熱処理の異なる試料では ${ }^{11} \mathrm{~B}^{+}$イオン 分布像から B の存在状態の違いが，さらに線分析でマト リックス固溶 B 量の違いが直接的に分析でき得たので, 次に実用鋼程度の Total B=15 ppm のものについても 同様の調查を行つた.

(B) Total B=15 ppm 材の IMMA 分析

IMMA による調査は Total $\mathrm{B}=85 \mathrm{ppm}$ 材と同様金 相組織と一致する場所で行つた。 ${ }^{11} \mathrm{~B}+$ イオン分布像観 察ではB 量が少ないために熱処理(3)でオーステナイト粒 界と粒内に多数の小さな析出物が存在することが組織と 一致して観察されるのみであらた．このことから金相組 織之一致したオーステナイト粒界を含めた個所での線分 析( Total B $=85 \mathrm{ppm}$ 調査時と同一線分析)による B 分析 を行つた.この結果を Photo. 3 に示すが, 熱処理, (1) (2)ではマトリックス固溶Bが高感度で検出されていると 同時にオーステナイト粒界でBが濃化しているのが明瞭 に検出された。熱処理(1) と(2)の線分析結果を比較した場 合, 熱処理(2)の二段焼入材の注らがオーステナイト粒界 での偏析量が大きく, マトリックス固溶 B 量は若干低く なつている結果が得られた。. 熱処理(3)での縦軸イオン強 度值が高くなつているのは, 多数存在する析出物からの Bが検出されているためで8)，マトリックス固溶 B 量は 熱処理(1)，(2)に比較してほとんど検出されていない.

このように Total $\mathrm{B}=15 \mathrm{ppm}$ と実用鋼程度に低い材 料のものについても粒界偏析, 析出扰よびマトリックス 固溶 B を光学顕微鏡組織と一致対応させて直接的に高感 度な分析が可能なことが判明した。

(C) 同一 B 量添加材にお打る $\mathrm{N}$ 量の影響調査

以上のように IMMA では鋼中に微量添加される Bを 直接的に高感度分析可能なことが，実験により確認され たので, 次に Total B=15 ppm と等量のBを添加した 材料で $\mathrm{N}$ 量が変化した場合についてのマトリックス固溶 $\mathrm{B}$ 量の直接分析を試みた。従来より $\mathrm{N}$ 量が多いものでは 添加 B は BN として析出するため固溶 B 量は減少し, N 量が少ないものでは BNとしての析出が減少するため固 溶 B 量が増大し，この結果として前者では焼入性低下， 後者は焼入性の向上に連なることが知られている。本調 査に用いた試料は Table 1 に示した Sample A ( N 量 $=20 \mathrm{ppm})$ と Sample B $(\mathrm{N}$ 量 $=60 \mathrm{ppm})$ である.この 2 試料についてのショミニー試験結果 $\left(\right.$ As roll $\rightarrow 930^{\circ} \mathrm{C}$ $\times 30 \mathrm{~min})$ は Fig. 2 に示すよらに高N材では低N材に 較べて焼入硬度の低下すなわら焼入性の低下が明瞭に認 められている9). IMMA では前述の線分析法による同 一感度での B 析出物のない個所でのマトリックス固溶 B 


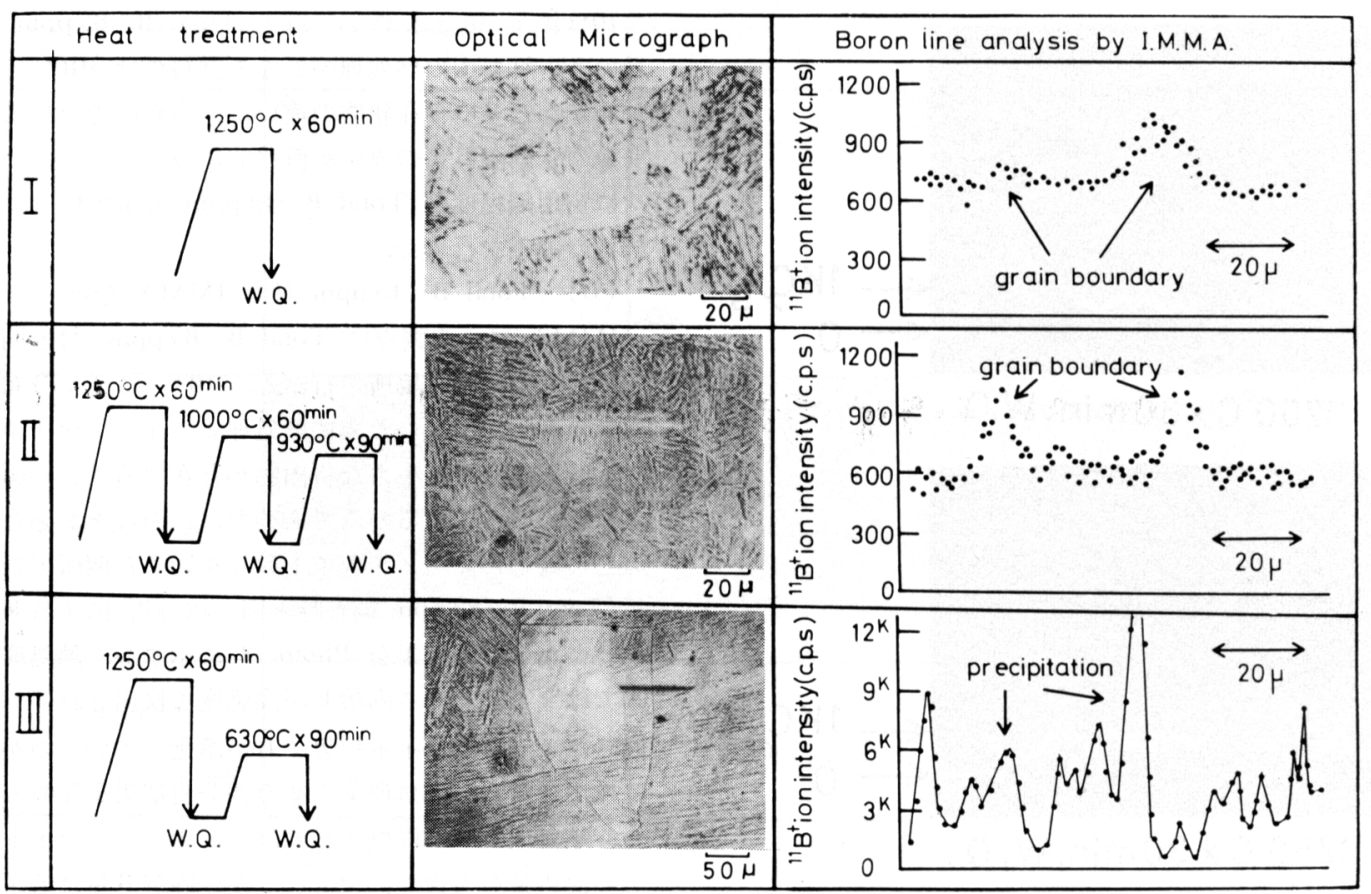

Photo. 3. Step scan analysis of $\mathrm{B}^{+}(\mathrm{B}=15 \mathrm{ppm})$.

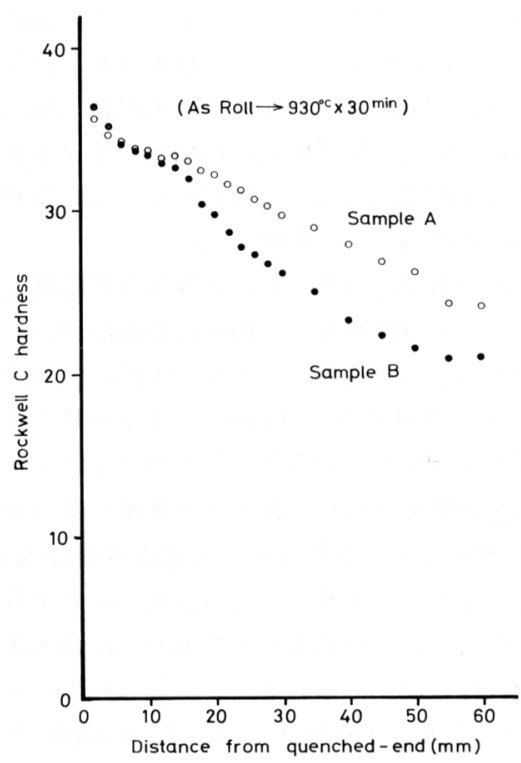

Fig. 2. The result of the Jominy tests.

量を比較調査したところ Photo. 4 に示すように高N材 では低 $\mathrm{N}$ 材に較べて固溶 B 量が明らかに少ない結果が得 られ従来からの知見 ${ }^{1)},{ }^{11}$ 亿一致した情報が直接的に求ま つた. このことから今後このようにマトリックス固溶 B

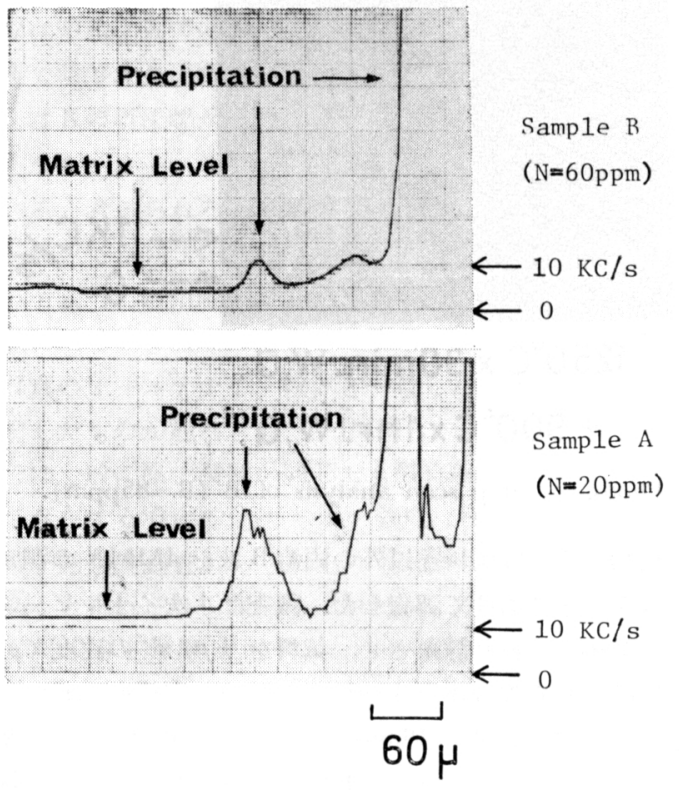

Photo. 4. Matrix level of $\mathrm{B}^{+}$in steel (B in steel $(\mathrm{B}=15 \mathrm{ppm})$ compared with hardenabillity.

量を直接分析することにより焼入性, 機械的性質との対 応が直接に解明可能と考えられる. 
Table 2. IMMA measurement of $\mathbf{B}^{+}$from various heat-treates steels.

$$
\mathrm{B}(=85 \mathrm{ppm}) \text { intensity }
$$

at $100 \mathrm{~s}$

\begin{tabular}{c|c|c}
\hline & Matrix $(2 \mu \phi)$ & Area $(200 \mu \times 160 \mu)$ \\
\hline I & $2.7 \times 10^{4}$ & $3.9 \times 10^{4}$ \\
\hline II & $2.9 \times 10^{4}$ & $3.0 \times 10^{4}$ \\
\hline III & $0.36 \times 10^{4}$ & $11.9 \times 10^{4}$ \\
\hline
\end{tabular}

(D) B の定量的測定

\section{a. Total B と固溶Bの定量的測定}

次に Total B と固溶 B の定量的測定を前述の Total $\mathrm{B}=85 \mathrm{ppm}$ の熱処理を変化した試料について調査した。 結果を Table 2 に示すが材料の平均的な B 量を測定す るために測定面積を $200 \mu \times 160 \mu$ と拡げ，偏析・析出 物を含めた面積での B のイオン強度を測定すると Total B 量が同じであつても必ずしも同じ測定值とはならず, 添加 Bをほとんどすべて析出させる熱処理(3)を行つたも のでは, 熱処理(1), (2)での测筀值より $3 \sim 4$ 倍高くなつ ている.

IMMA では例えば鋼中の炭素を分析する場合にも析 出物からの 2 次イオン強度が高く検出される傾向があり $\mathbf{8}^{\prime}$, 従つて化合物の存在形態により 2 次イオン強度が大 幅に変化する。このためこのよらに測定面積を拡げて 平均的な B 量を比較測定しょうとする場合には, 熱処理 を同じにして存在形態を揃えた上で此較測定することが 必要である. 1 次イオンビームを $2 \mu \phi$ と細く絞つて偏 析・析出のない個所でのマトリックス固溶Bを測定する 場合には熱処理(3)での B イオン強度は熱処理(1), (2)に較 べて約 1 析低い值が得られ，したがつて固溶 B の差は熱 処理状態が異なる試料間でも直接的な量の比較が可能で ある。

\section{b. CARISMA による定量}

IMMA での坛量補正計算プログラムとして局所熱平 衡プラズマを仮定した CARISMA があり，ほとんどの 元素定量についてオーダー的に合うと言われている10). 我々もこのプログラムを有していることから, Total B $=85$ および $15 \mathrm{ppm}$ 熱処理材でのマトリックス固溶 $\mathrm{B}$ 量の定量計算を試みた. 結果をFig. 3 に示すが，横 軸, 縦軸は沶のおの化学分析, CARISMA による固溶 Bの定量結果を示したものである.この結果からも明ら かなよらに CARISMAでの定量值は化学分析とは直線 関係が得られているが，絶対量については 5〜6倍一定 に高くずれている. この要因については CARISMA 計 算での内標準元素の選択，1 次イオン加速電圧，電流密

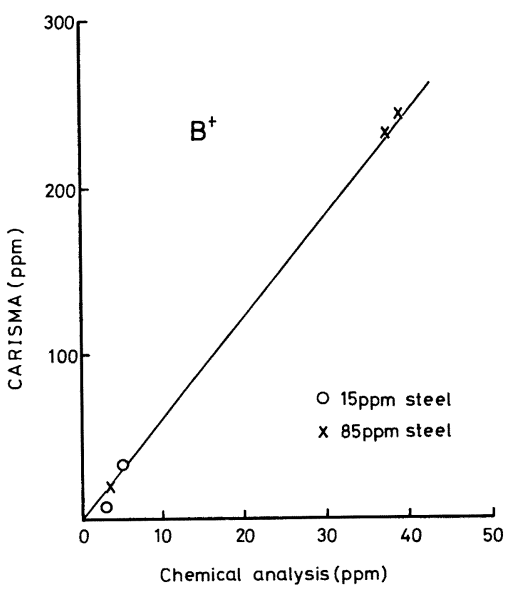

Fig. 3. Calibration curve of $\mathrm{B}^{+}$corrected by CARISMA (internal standard $\mathrm{Fe}$ and $\mathrm{Ni}$.

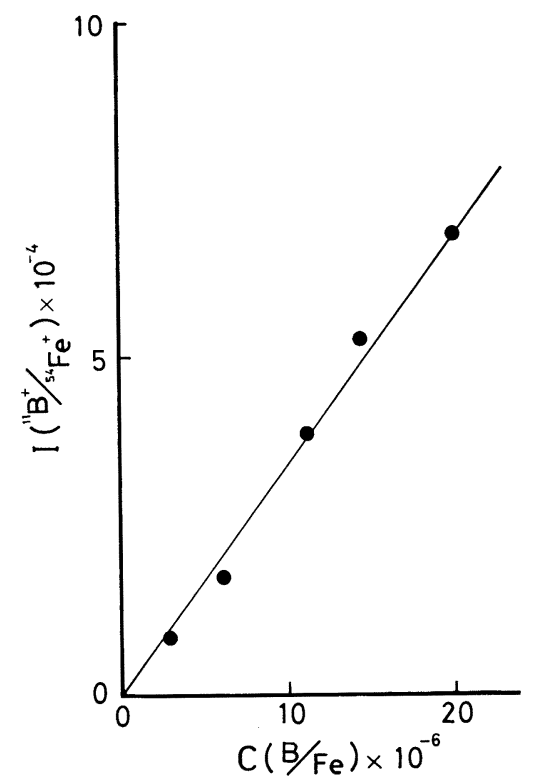

Fig. 4. Calibration curve of boron in steel by IMMA (Pri. ion; $\mathrm{O}_{2}^{+} 20 \mathrm{keV}$ ).

度の影響などが考えられる。これらの絶対值のずれにつ いてはB以外の元素についても一般的に認められ実用的 には原子濃度比 $[\mathrm{C}(\mathrm{x} / \mathrm{Fe})] \mathrm{vs} 2$ 次イオン強度比 $[\mathrm{I}$ $(\mathrm{x} / \mathrm{Fe})]$ より求まる検量線を用いた定量分析が精度的に も有効である. Fig. 4 にBの検量線を示すが直線性は きわめて良好である。 


\section{6. 結言}

以上 ARL 製 IMMA を用いて鋼中の微量 Bの存在 形態，固溶量の差およびオーステナイト粒界偏析した B を金相組織と対応させて局所分析を行い，IMMA では これらの直接的な高感度分析が可能なこと, さらには定 量的な測定が可能なことを見出した。これにより今後治 金学上の問題との対応により，Bの効果・影響などが直 接的に測定可能であると考える.

終わりにめたり本研究を達成するための多くの有益な ご指導拉よび材料の提供を賜わつた住友金属工業(株)中 央技術研究所の各位に対して感謝の意を表します。

\section{文献}

1) Y. Ohmori: Trans. ISIJ, 11 (1971), p. 339
2) J. M. WAlsh and B. H. Kear: Met. Trans., 6A (1975), p. 226

3 ) $P$. Maitrepierre, $D$. Thivellier, and $R$. Tricot: Met. Trans., 6A (1975), p. 287

4 ) B. S. Carpenter: Anal. Chim. Acta, 81 (1976), p. 409

5 ) T. Funakoshi: Trans ISIJ, 17 (1977), p. 419

6) ASTM STP No. 485 p. 167

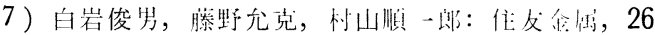
(1974) 4

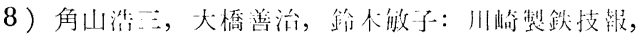
$7(1975)$, p. 1

9 ) 渡辺征一，大行泰夫：佚と锎，62(1976)，p. 75

10) $C$. A. Andersen and $J . R$. Hinthone: Anal. Chem., 45 (1973)

11) $K$. Yamanaka and $Y$. Ohmori: Trans. ISIJ, (1980), p. 404 